Jurnal llmu Administrasi Publik 6 (1) (2018): 58-71

Jurnal Administrasi Publik

http://ojs.uma.ac.id/index.php/publikauma

\title{
ANALISIS PELAKSANAAN PERENCANAAN PEMBANGUNAN DI KELURAHAN SEI PUTIH TENGAH KECAMATAN MEDAN PETISAH KOTA MEDAN
}

\author{
Aisyah Oktaviani Putri, Sirojuzilam dan Abdul Kadir * \\ Pascasarjana Universitas Medan Area, \\ Medan, Indonesia
}

Diterima Februari 2018; Disetujui April 2018; Dipublikasikan Juni 2018

\begin{abstract}
Abstrak
Proses perencanaan pembangunan daerah yang berlangsung secara umum masih memiliki beberapa kekurangan. Yang menjadi kekurangan dalam hasil pelaksanaan perencanaan pembangunan adalah (1) faktor anggaran. (2) sumber daya masyarakat yang umumnya masih lemah. (3) sumber daya organisasi atau perangkat daerah yang belum memadai. (4) pergeseran usulan kegiatan. Serta faktor lainnya seperti mekanisme penyampaian usulan kegiatan yang belum baku dan peran aktor perumus kebijakan publik yang signifikan. Tujuan penelitian ini ialah untuk mengetahui dan mendeskripsikan (1) bagaimana pelaksanaan perencanaan pembangunan di Kelurahan Sei Putih Tengah terhadap infrastruktur, berupa pembangunan jalan dan perbaikan di bidang fisik. (2) faktor-faktor yang menjadi kendala tidak berjalannya pelaksanaan perencanaan pembangunan tersebut. Penelitian ini menggunakan metode deskriptif kualitatif. Yang menjadi sampel dalam penelitian ini berjumlah $\|$ orang. Pengumpulan data di peroleh dari wawancara, dokumentasi dan observasi. Setelah data di peroleh kemudian di analisis dengan menggunakan reduksi data, penyajian data dan verifikasi.
\end{abstract}

Kata Kunci : Analisis, Pelaksanaan, Perencanaan Pembangunan

\begin{abstract}
The process of regional development planning that takes place in general still has some shortcomings. The shortcomings in the results of the implementation of development planning are (1) budget factor. (2) community resources are generally weak. (3) inadequate organizational or regional device resources. (4) shifting activity proposal. As well as other factors such as the mechanism of submission of proposed activities that have not been standardized and the role of actors public policy makers are significant. The purpose of this study is to know and describe (I) how the implementation of development planning in Sei Putih Tengah Urban to infrastructure, in the form of road construction and improvement in physical field. (2) the factors that become obstacles not the implementation of the development plan. This study used descriptive qualitative method. The sample in this study amounted to II people. Data collection was obtained from interviews, documentation and observation. After the data obtained then in the analysis by using data reduction, data presentation and verification.
\end{abstract}

Keywords: Analysis, Implementation, Development Planning.

How to Cite : Putri, O., A Sirojuzilam dan Kadir. A, (2018). Analisis Pelaksanaan Perencanaan Pembangunan Di Kelurahan Sei Putih Tengah Kecamatan Medan Petisah Kota Medan, 6 (1): 58-71

$\begin{array}{lr}{ }^{*} \text { Corresponding author: } & \text { P-ISSN-2549-9165 } \\ \text { E-mail: aisya_oktaviani@yahoo.com } & \text { e-ISSN -2580-2011 }\end{array}$




\section{PENDAHULUAN}

Perencanaan dan pembangunan merupakan suatu kesatuan yang tidak dapat dipisahkan, ibarat satu tubuh yang diantara satu organ dengan organ lainnya memiliki keterhubungan yang melekat, karena pembangunan membutuhkan perencanaan dan perencanaan harus mewujud dalam pembangunan, mulai dari pemerintahan pusat sampai pada tingkat pemerintahan daerah. Dalam struktur pemerintahan pusat dikenal dengan Badan Perencanaan Pembangunan Nasional (BAPPENAS) dan dalam struktur pemerintahan daerah pada umumnya disebut dengan Badan Perencanaan Pembangunan Daerah (BAPPEDA). Mindset dalam proses penyusunan RKPD nampaknya masih sebatas pada retoris dan belum sepenuhnya tercermin dalam keseluruhan proses penyusunan RKPD. Bahkan yang menjadi catatan penting adalah pola pikir dan cara pandang lama masih cukup kental mewarnai proses RKPD, misalnya cenderung liniear dan belum mampu melihat masalah secara holistik. (Kuncoro, 2012:3).

Dalam rangka mewujudkan sistem perencanaan pembangunan yang ideal, maka dibutuhkan apa yang disebut dengan tahapan-tahapan, sebagaimana juga sudah terdefinisikan di dalam

Undang-Undang No. 25 Tahun 2004 tentang Sistem Perencanaan Pembangunan Nasional (SPPN) disebutkan bahwa tahapan tersebut meliputi penyusunan rencana, penetapan rencana, pengendalian pelaksana rencana, dan evaluasi pelaksanaan rencana. Perencanaan pembangunan daerah seharusnya mencerminkan kebutuhan realitas suatu daerah, sebagaimana dinyatakan Kuncoro (2012:43), bahwa perencanaan pembangunan daerah tidak hanya perencanaan dari suatu daerah, tetapi perencanaan untuk suatu daerah. Perencanaan pembangunan daerah berfungsi sebagai perencanaan untuk memperbaiki penggunaan sumber daya-sumber daya publik yang tersedia di daerah tersebut. Sehingga menjadi penting dalam proses penyusunannya dan harus bersifat aspiratif dan menggunakan pendekatan perencanaan yang tepat. Badan Perencanaan Pembangunan Daerah (BAPPEDA), dalam melaksanakan pembangunan tentu melalui beberapa proses perencanaan pembangunan, mulai dari Rencana Pembangunan Jangka Panjang Daerah (RPJPD), Rencana Pembangunan Jangka Menengah Daerah (RPJMD), Rencana Strategis Satuan Kerja Perangkat Daerah (Renstra SKPD), 
Rencana Kerja Pembangunan Daerah (RKPD) sampai pada Rencana Kerja Satuan Kerja Perangkat Daerah (Renja SKPD), hal tersebut adalah merupakan tata urutan hierarki yang bersifat bottom up-top down. Sebagaimanan juga disebutkan di dalam Peraturan Menteri Dalam Negeri (PERMENDAGRI) No. 54 Tahun 2010, tentang Pelaksanaan Peraturan Pemerintah No. 8 Tahun 2008 tentang tahapan, tata cara penyusunan, pengendalian, dan evaluasi pelaksanaan rencana pembangunan daerah. Pada umumnya perencanaan pembangunan daerah di Indonesia mengenal empat pendekatan, sebagaimana juga disebutkan di dalam PERMENDAGRI No. 54 Tahun 2010 Pasal 6, diantaranya adalah teknokratis, partisipatif, politis dan top downbottom up. Sebagaimana diamanatkan dalam Undang-Undang No. 25 Tahun 2004 tentang Sistem Perencanaan Pembangunan Nasional, bangsa ini harus memiliki sistem perencanaan pembangunan yang jelas, baik untuk tingkat desa/kelurahan, kabupaten/kota, provinsi hingga pusat. untuk mewujudkan sistem tersebut pemerintah telah membentuk musyawarahperencanaan pembangunan (musrenbang). Melalui Musrenbang inilah dicari apa sebenarnya yang menjadi keinginan dan kebutuhan rakyat.

Walau akhirnya lebih banyak keinginan dan kebutuhan yang tidak dapat direalisasikan ke dalam programprogram nyata di lapangan, namun sebagai alat adanya mekanisme penjaringan aspirasi rakyat, musrenbang dinilai sebagai mediasi yang masih pantas untuk terus di jalankan. Munculnya isu Good Governance dalam pembangunan di Indonesia didorongoleh adanya dinamika yang menuntut perubahan-perubahan disisi pemerintah atau pun disisi warga. Pemerintah diharapkan menjadi lebih demokratis, efektif menjalankan fungsi pelayanan publik, tanggap, serta mampu menyusun kebijakan yang dapat menjamin hak-hak asasi dan keadilan sosial masing-masing warganya. Sejalan dengan harapan terhadap peran negara tersebut, warga juga diharapkan untuk menjadi warga yang memiliki kesadaran akan hak dan kewajibannya, bersedia berpartisipasi aktif dalam penyelenggaraan urusan publik, dan tidak apatis. Dilaksanakan tata cara dan tahapan perencanaan daerah bertujuan untuk mengefektifkan proses pemerintahan yang baik melalui pemanfaatan sumber daya publik yang berdampak pada percepatan proses perubahan sosial bagi peningkatan 
kesejahteraan masyarakat, atau terarahnya proses pengembangan ekonomi dan kemampuan masyarakat, dan tercapainya tujuan pelayanan publik.

Kondisi perekonomian yang membaik tidak dapat dilepaskan dari peran penting infrastruktur. Kegiatan pembangunan, rehabilitasi, pemeliharaan serta subsidi operasi telah berhasil meningkatkan aksesibilitas, kapasitas, kualitas, dan jangkauan pelayanan berbagai infrastruktur, yang pada gilirannya mampu memberikan dukungan kepada berbagai sektor perekonomian seperti pertanian, industri pengolahan, perdagangan, dan pembangunan daerah.Menyadari pentingnya pembangunan infrastruktur sebagai proses dalam pencapaian tujuan pembangunan nasional dan daerah, maka perlu kiranya disiapkan dengan baik perencanaan dan penganggarannya. Dalam rangka perwujudan perencanaan dan penganggaran yang baik ini maka semua dokumen perencanaan dan penganggaran pada dinas pengelola infrastruktur ini harus dijaga konsistensinya.

Hal ini dapat dijumpai pada sejumlah pemerintah daerah yang melaksanakan proses perencanaan pembangunan daerah. Meskipun secara normatif sistem perencanaan nasional telah berpedoman pada satu regulasi, tapi proses perencanaan pembangunan tetap berlangsung berbeda antar daerah, tergantung kapasitas dan kondisi kedaerahan pemerintah daerah yang bersangkutan sehingga dipastikan hasilnya pun akan berbeda satu sama lain. Sungguhpun demikian ada suatu kecenderungan yang sama dalam perencanaan pembangunan daerah, yakni tidak terakomodirnya aspirasi masyarakat dalam pembangunan. Padahal ruang-ruang publik telah dibuka dengan turut terdesentralisasinya perencanaan pembangunan.(Kuncoro, 2000; Todaro, 2000).

Pembangunan merupakan proses yang tanpa henti, begitu pula dengan pembangunan masyarakat, maka sangat diperlukan kejelian dan kepekaan untuk menemukan kelemahan-kelemahan dan masalah-masalah yang muncul dalam perencanaan maupun pelaksanaan program pembangunan. Ada sejumlah faktor yang membantu tercapainya keberhasilan pembangunan, yaitu:

1. Adanya perencanaan yang realistis disesuaikan dengan kondisi sosial dan nasional.

2. Adanya kesungguhan untuk melaksanakan kegiatan pembangunan sesuai dengan apa yang direncanakan. 
3. Adanya kepemimpinan yang konsekuen dan konsisten mengelola upaya pembangunan dari satu tahap ke tahap berikutnya sesuai denganrencana.

Seringkali dalam proses perencanaan pembangunan, tidak menghasilkan sebuah perencanaan yang baik, atau perencanaan yang tidak sesuai dengan tujuan pembangunan masyarakat. Dalam pembangunan terdapat fasos dan fasum. Dimana fasos ini adalah fasilitas sosial dan fasum itu sendiri adalah fasilitas umum. Arti atau pengertian fasilitas umum adalah fasilitas yang diadakan untuk kepentingan umum. Contoh dari fasilitas umum (fasum) adalah seperti jalan,saluran air, jembatan,fly over, alat penerangan umum, listrik, banjir kanal, trotoar, tempat pembuangan sampah. Sedangkan arti atau pengertian fasilitas sosial adalah fasilitas yang diadakan oleh pemerintah atau pihak swasta yang dapat dimanfaatkan oleh masyarakat umum. Contoh dari fasilitas sosial (fasos) adalah seperti puskemas, klinik, sekolah, tempat ibadah, pasar, tempat rekreasi, taman bermain, tempat olahraga, ruang serbaguna, makam.

Fasilitas umum dan fasilitas sosial adalah milik bersama yang harus dijaga dan dirawat dengan baik agar bisa selalu dimanfaatkan secara maksimal.
Warga masyarakat dapat saling bahumembahu untuk membangun dan memperbaiki fasum atau fasos itu sendiri jika memang sangat diperlukan tanpa bergantung kepada pemerintah.

Fasilitas umum maupun fasilitas sosial yang di buat oleh pemerintah yang dirusak orang-orang yang tidak bertanggung jawab akan merugikan masyarakat. Fasum dan fasos yang disediakan oleh pemerintah dibiayai oleh dana yang sebagian besar didapat dari pajak dan retribusi. Pajak dan retribusi dikumpulkan oleh pemerintah dari masyarakat, sehingga fasilitas umum dan fasilitas sosial merupakan milik masyarakat umum. Dengan adanya permasalahan tersebut dapat menjadi kendala atau menghambat kemajuan dari pada kesejahteraan masyarakat.

\section{Metode Penelitian}

Menurut Moleong (2005), penelitian kualitatif adalah penelitian yang bermaksud untuk memahami fenomena tentang apa yang dialami oleh subjek penelitian, misalnya perilaku, persepsi, motivasi, tindakan, dan lain sebagainya.Proses penelitian kualitatif ini melibatkan upaya seperti mengajukan pertanyaan dan mengumpulkan data yang spesifik dari para partisipan, menganalisis data (Creswell 2010:5). 
Alasan lain penelitian ini menggunakan metode deskriptif karena ingin memahami secara mendalam bagaimana pelaksanaan perencanaan pembangunan tersebut berlangsung terutama dalam pembangunan daerah di tahun 2015.

Penelitian ini menggunakan metode Deskriptif dengan teknik analisis Kualitatif dikarenakan permasalahan yang belum jelas, kompleks dan penuh makna. Model analisis yang di gunakan adalan William Dunn (2000:1) yaitu, memberikan definisi analisis kebijakan adalah aktivitas menciptakan pengetahuan tentang dan dalam proses pembuatan kebijakan variabel. Proses penelitian kualitatif ini melibatkan upaya seperti mengajukan pertanyaan dan mengumpulkan data yang spesifik dari para partisipan, menganalisis data (Creswell 2010:5). Alasan lain penelitian ini menggunakan metode deskriptif karena ingin memahami secara mendalam bagaimana pelaksanaan perencanaan pembangunan tersebut berlangsung terutama dalam pembangunan daerah di tahun 2015.

Lokasi Penelitian ini akan dilakukan di Kelurahan Sei Putih Tengah. Yang beralamat di jalan. Periuk No. 53 Kota Medan. Adapun yang menjadi alasan bagi peneliti dalam menentukan lokasi di atas, karena ingin menganalisa lebih jauh bagaimana pelaksanaan infrastruktur dari perencanaan pembangunan daerah tersebut yang belum sepenuhnya terealisasi dengan baik. Dan ingin mengetahui bagaimana pelaksanaan tersebut berjalan sesuai dengan kebutuhan masyarakat.

$$
\text { Penelitian ini dilakukan pada }
$$

bulan Maret 2017 - April 2017.

Langkah-langkah analisa data yang digunakan dalam penelitian ini adalah sebagai berikut (Suyanto, 2005:171): (1) Observasi, yaitu proses pengamatan yang dilakukan secara intens terhadap objek yang akan diteliti. (2) Wawancara mendalam (depth interview). Wawancara mendalam adalah suatu cara mengumpulkan data atau informasi dengan cara langsung bertatap muka dengan informan agar mendapatkan data lengkap dan mendalam. Wawancara ini dilakukan dengan berulang-ulang secara intensif. Adapun alat dalam pengambilan data seperti, tape recorder, handphone, foto dan data yang termasuk ke dalam dokumentasi. (3) Dokumentasi. Studi dokumentasi dalam pengumpulan data penelitian dimaksudkan sebagai cara mengumpulkan data dengan mempelajari dan mencatat bagian-bagian yang dianggap penting dan berbagai dokumen resmi yang dianggap baik dan ada pengaruhnya dengan lokasi penelitian. Menurut Miles dan Huberman (2010), teknik analisis data dengan model 
interaktif terdiri atas empat tahapan yang harus dilakukan yaitu pengumpulan data, reduksi data, display data dan tahap penarikan kesimpulan atau verifikasi. Untuk meningkatkan kualitas penelitian digunakan teknik triangulasi yaitu teknik pemeriksaan keabsahan data yang memanfaatkan sesuatu yang lain diluar data itu untuk keperluan pengecekan atau sebagai pembanding terhadap data tersebut. Kredibilitas Apakah proses dan hasil penelitian dapat diterima atau dipercaya. Beberapa kriteria dalam menilai adalah lama penelitian, observasi yang detail, analisis membandingkan dengan hasil penelitian, yaitu:Pengamatan yang terus menerus, untuk menemukan ciri-ciri dan unsur unsur dalam situasi yang sangat relevan dengan persoalan atau isu yang sedang diteliti, serta memuaskan diri pada hal-hal tersebut secara rinci.Dependability yaitu apakah hasil penelitian mengacu padatingkat konsistensi peneliti dalam mengumpulkan data, membentuk, dan menggunakan konsep-konsep ketika membuat interprestasi untuk menarik kesimpulan (Kriyantono, 2006:58).

\section{Hasil dan Pembahasan}

Hasil penelitian menunjukkan bahwa praktek pelaksanaan perencanaan pembangunan yang berlangsung selama ini di Kelurahan Sei Putih Tengah dinilai belum efektif. Dari hasil pengamatan kegiatan terealisasi di tahun 2015, serapan usulan kegiatan yang berasal dari Musrenbang hanya mencapai beberapa persen saja. Ada beberapa faktor yang mempengaruhi usulan program prioritas belum terpenuhi atau berjalan. Data menunjukkan, dari semua usulan masyarakat setiap tahunnya, program yang terserap dalam perencanaan dan penganggaran hanya sepersekian persen. Padahal, masyarakat yang awalnya antusias ikut dalam proses musrembang menyangka sebagian besar programnya akan direalisasikan. Kekecewaan ini berimplikasi pada menurunnya tingkat kehadiran dalam proses tahun berikutnya. Kurangnya keaktifan masyarakat pada kegiatan pembangunan lainnya semakin menurun.

Sesuai observasi dan wawancara yang peneliti lakukan maka didapat apa saja hal yang menjadi kendala mengapa usulan program yang di dapat dari Musrenbang tidak sepenuhnya terealisasi. Dapat dijelaskan ke dalam beberapa faktor dibawah ini: 1) Jumlah dana yang di anggarkan untuk pembangunan hasil kegiatan Musrenbang masih kurang mencukupi, bahwa dari semua yang di usulkan hanya sebagian yang menjadi rekapitulasi usulan program, di 
karenakan anggaran yang masih minim untuk dapat memenuhi semua kebutuhan masyarakat yang berimplikasi pada pembangunan atau program yang hanya sebagian dapat terlaksana, namun sisa dari pada program tersebut masih mengambang belum berjalan. Dari semua usulan anggaran tersebut maka diperkirakan hanya sebagian anggaran yang bisa tercapai.Artinya bahwa selama ini perencanaan pembangunan bukan didasarkan atas penggalian aspirasi dari masyarakat, tetapi lebih pada penyesuaian alokasi anggaran. Apabila anggaranya dirasakan mencukupi, maka program dapat dilaksanakan dan sebaliknya apabila alokasi anggaran tidak mampu menampung seluruh kegiatan, maka akan dipilih mana kegiatan yang paling urgen dan mendesak untuk dilaksanakan. Data menunjukkan, dari semua usulan masyarakat setiap tahunnya, program yang terserap dalam perencanaan dan penganggaran hanya sepersekian persen. Padahal, masyarakat yang awalnya antusias ikut dalam proses musrembang menyangka sebagian besar programnya akan direalisasikan. Kekecewaan ini berimplikasi pada menurunnya tingkat kehadiran dalam proses tahun berikutnya. Lebih parah lagi keaktifan masyarakat pada kegiatan pembangunann lainnya semakin menurun.

Kendala usulan masyarakat menyebabkan program tidak dapat terakomodirkarena diluar kewenangan dan kemampuan kota, hal inidilatar belakangi oleh masih rendahnya pendidikan masyarakat mengenai hal-hal teknis sehingga dalam pengambilan keputusan sering kali tidak selaras dengan kewenangan dan kemampuan kota.Sumber daya manusia yang masih lemah di kalangan masyarakat tergambar dari usulan yang disampaikan.

Pihak masyarakat di Kelurahan dan pemerintah mengidentifikasi bahwa rendahnya pengetahuan masyarakat disebabkan tidak adanya fasilitas sumber bacaan di wilayah itu. Sebagai solusinya mereka kemudian mengusulkan untuk dibangunkan "gedung perpustakaan". Tetapi sebagian masyarakat hanya berpikir soal membangun gedung, tetapi lupa berpikir dan mengusulkan bagaimana menyediakan buku atau bahan bacaan untuk perpustakaan itu, lupa mengusulkan kepengurusan untuk mengelola perpustakaan itu. Kondisi seperti diatas mungkin tidak akan terjadi kalau mereka berpikir dulu soal "outcome" misalnya meningkatkan minat baca $50 \%$ warga masyarakat. 
Dari outcome tersebut nantinya bisa diidentifikasi output yang diperlukan. Misalnya, adanya gedung perpustakaan, buku atau bahan bacaan, tenaga pengelola perpustakaan, kesadaran masyarakat untuk datang ke perpustakaan.

Dari gambaran tersebut nampaknya untuk pemerintah dan masyarakat memang perlu didorong untuk memahami alur berpikir logis (logical framework) sebuah perencanaan. Selain itu pola pikir yang ada yang cenderung berorientasi proyek (yang berorientasi jangka pendek dan berkonotasi uang) menjadi orientasi program (orientasi jangka panjang dan lebih berkonotasi sebagai gerakan pembangunan).

Secara umum masyarakat hanya mengajukan usulan yang bersifat fisik, dan seringkali usulan tersebut tidak mewakili kebutuhan masyarakat yang sebenarnya namun hanya sebatas keinginan. Masyarakat belum sepenuhnya mampu mengidentifikasi permasalahan atau kebutuhan mereka. Oleh karena itu pihak pemerintah daerah harus selektif dalam proses penentuan prioritas ketika mengakomodasi usulan mereka.Oleh sebab itu pendampingan masyarakat oleh Dinas dan pihak yang ahli dalam bidang permasalahan sangatlah penting sehingga dapat meminimalisir penolakan usulan dan usulan masyarakat yang diaspirasikan tepat sasaran

Faktor sumber daya organisasi atau perangkat daerah juga mempengaruhi proses berjalannya usulan kegiatan menuju realisasi, meliputi anggaran kegiatan dan kondisi sumber daya manusia dalam organisasi tersebut. Keterbatasan anggaran yang tersedia menyebabkan pihak perangkat daerah harus selektif dalam menentukan prioritas kegiatan, sehingga seringkali ada usulan kegiatan yang tidak bisa diakomodasi atau tidak dapat terealisasi. Proses seleksi usulan salah satunya dengan melalui tahap verifikasi awal yaitu survey lapangan yangdilakukan oleh personil perangkat daerah. Kekurangan petugas survey lapangan mengakibatkan SKPD terlambat dalam pengecekan lokasi usulan yang harusnyadilakukan diawal proses perencanaan. Akibatnya dokumen perencanaan tidakdapat mencantumkan detail lokasi kegiatan.

Proses seleksi usulan selain surveyyaitu pemberian pertimbangan dari perangkat daerah mengenai layak atau tidaknyasuatu usulan masyarakat diakomodasi. Untuk ini dibutuhkan sumber daya manusia organisasi yang mampu memberikan masukan yang tepat untuk perencanaan yang lebih baik. 
Kelemahan yang ditemui dalam mekanisme perencanaan pembangunan diiringi oleh kekuatan pengaruh dari aktor-aktor perumus kebijakan publik yang melekat sepanjang tahapan proses perencanaan di daerah menimbulkan pergeseran usulan kegiatan setiap tahun. Berdasarkan informasi yang diperoleh dari hasil wawancara dengan informan Lurah Sei Putih Tengah disimpulkan ada delapan tipe pergeseran jenis atau volume atau lokasi kegiatan berdasarkan proses yang terjadi, yaitu:

a. Usulan kegiatan tidak detail

Usulan kegiatan yang tidak mencantumkan spesifikasi lokasi akan menyulitkan tim verifikasi di lapangan, sehingga usulan yang seperti ini cenderung ditinggalkan atau diabaikan. Sementara usulan dari sumber lain yang lebih detail akan menjadi prioritas pemerintah daerah untuk diverifikasi sehingga berpeluang untuk dianggarkan.

b. Usulan kegiatan bukan merupakan kebutuhan yang mendesak masyarakat.

Adakalanya melakukan identifikasi masalah yang tidak tepat, sehingga mereka mengajukan usulan kegiatan sebagai solusi atas keinginan mereka, bukan kebutuhan yang sebenarnya. Melalui verifikasi, pemerintah daerah akan mengecek kondisi yang sebenarnya sebelum usulan diakomodasi c. Hasil survey menunjukkan lokasi lain yang lebih prioritas untuk ditangani.

$$
\text { Hal ini bisa disebabkan oleh }
$$

ketidaktepatan masyarakat dalam menentukan masalah mereka (keinginan bukan kebutuhan). Sebab lain adalah kurang cermatnya atau keterbatasan masyarakat dalam melakukan kajian terhadaplingkungan tempat tinggal mereka dan sekitarnya, sehingga lokasi yang lebih prioritas untuk ditangani justru terabaikan dan akhirnya ditemukan oleh tim survey SKPD.

d. Pengalihan jenis pekerjaan

Hal ini biasanya terjadi setelah lokasi yang diusulkan diverifikasi oleh timsurvey SKPD, kemudian berdasarkan pertimbangan teknis dan efisiensi dialihkan kepada jenis pekerjaan yang lebih tepat untuk penanganannya.

e. Pengurangan volume pekerjaan

Sejalan dengan penjelasan poin diatas, hal ini juga dilakukan dalam rangka efisiensi karena keterbatasan anggaran yang dialokasikan oleh pemerintah daerah untuk pekerjaan tersebut.

f. Pekerjaan dilakukan bertahap

Hal ini tidak berarti bahwa pekerjaan dilaksanakan tidak sesuai dengan volume yang diusulkan, hanya saja pekerjaan dilakukan bertahap karena keterbatasan anggaran dan akan 
dilanjutkan atau diselesaikan di tahun anggaran berikutnya.

g. Pemanfaatan kurang efektif

Kegiatan yang diusulkan oleh masyarakat perlu dipertimbangkan juga dari sisi efektivitas pemanfaatannya, sehingga dana yang dialokasikan tidak terbuang percuma dan fasilitas yang dibangun nantinya dapat dirasakan manfaatnya oleh orang banyak.

h. Pemerataan penerima manfaat

Pertimbangan ini dilakukan agar masyarakat merasakan keadilan dan upaya pemerataan kesejahteraan dari pemerintah daerah, sehingga setiap wilayah maupun kelompok masyarakat memiliki peluang yang sama untuk merasakan manfaat pembangunan dan kemajuan.

Proses perencanaan pembangunan daerah yang berlangsung secara umum masih memiliki beberapa kekurangan. Untuk mengoptimalkan keberhasilan perencanaan hingga ke tahap implementasi perlu upaya serius untuk membenahinya sejak proses pengajuan usulan kegiatan, penyusunan dokumen perencanaan dan anggaran hingga realisasi, termasuk dalam hal pengendalian atau evaluasi.

\section{Simpulan}

Berdasarkan hasil analisis serta data-data dari observasi peneliti maupun wancara yang peneliti lakukan diperoleh pelaksanaan perencanaan pembangunan di Kelurahan Sei Putih Tengah Kecamatan Medan Petisah dinilai belum efektif. Dari hasil pengamatan kegiatan terealisasi ditahun 2015, serapan usulan kegiatan yang berasal dari Musrenbang hanyasebagian. Hal ini disebabkan masih terdapatnya kelemahan-kelemahandalam pelaksanaan sehingga perlu pembenahan belum memadai, dan peran aktor perumus kebijakan publik yang signifikan. Ada beberapa hal yang jadi keluhan masyarakat tentang hasil pelaksanaan pasca Musrenbang Kelurahan yang belum terealisasi program mana yang ingin dikerjakan nantinya, dan banyaknya usulan sekadar memenuhi list program yang diajukan, tanpa ada jaminan berapa jumlah program yang terakomodasi.

Hasil pelaksanaan Musrenbang di Kelurahan Sei Putih Tengah belum benar-benar berjalan dengan sepenuhnya, hanya sebagian dan itupun harus menunggu beberapa tahun lamanya di sebabkan beberapa faktor diantaranya, yaitu:

Faktor anggaran, banyaknya prioritas pembangunan yang akandilaksanakan hasil dari penggalian aspirasi masyarakat, masih kurang diimbangi dengan dukungan anggaran 
yang memadai, sehingga tidaksemua program pembangunan dapat terealisasi.

Faktor keakuratan usulan kegiatan, usulan kegiatan yang diajukan olehmasyarakat mulai dari musrenbang Kelurahan kurang memilikikualitas untuk diprogramkan menjadi sebuah prioritas kebutuhan masyarakat, sehingga pada tahapan yang lebih tinggi usulan tersebut tidak terakomodasi.

Tidak terjaringnya programprogram yang diajukan juga terjadi karena beberapa faktor, seperti kesalahan postur anggaran, program yang bertentangan dengan norma hukum, atau SDM masyarakat yang masih lemah dan prioritas pembangunan daerah tidak sesuai dengan program, dan beberapa faktor lainnya.

\section{Daftar Pustaka}

Ainur Rahman dkk. Politik, Partisipasi dan Demokrasi dalam PembangunanMalang, Averroes Press, 2009.

Alexander, Abe. Perencanaan Daerah Memperkuat Prakarsa Rakyat Dalam Otonomi Daerah. Utama, 2001.
Dunn. William. Pengantar Analisis Kebijakan Publik. Gajah Mada Universal Press: Yogyakarta. 2003. Edmund M, Burke. Sebuah Pendekatan Partisipasi Dalam Perencanaan Kota: Yayasan Sugijanto Soegijoko, 2004.

Hamdi, Muchlis. Kebijakan Publik:

Proses, Analisis, dan Partisipasi, Jakarta: Ghalia Indonesia, 2014.

HAW. Widjaja. Otonomi Daerah dan Daerah Otonom. Jakarta, RajaGrafindoPersada, 2002.

Islamy, M. Irfan. Prinsip-prinsip Perumusan Kebijakan

Negara. Jakarta:Bumi Aksara, 2000.

Kriyantono, Rachmat. Teknik Praktis Riset Komunikasi, Jakarta:

Kencana Prenada Media Group, 2006.

Karianga, Hendra. Partisipasi Masyarakat Dalam Pengelolaan KeuanganDaerah: Perspektif Hukum dan Demokrasi, Jakarta: Kencana PrenadaMedia Group, 2011.

Kountor, D.M.S, Ronny. Metode Penelitian Untuk Penulisan Skripsi \& Tesis:PPM, 2003.

Moleong, Lexy J. Meteodologi Penelitian Kualitatif, Bandung: PT Remaja Rosdakarya, 2002.

Mulyana, Dedy. Teknik Praktis Riset Komunikasi, Jakarta: Kencana PrenadaMedia Group, 2006. 
Nasution, Zulkarnaen. Solidaritas Sosial Masyarakat Transisi, Padang: UNPPress, 2012.

Nugroho, D Riant. Kebijakan Publik, Formulasi, Implementasi danEvaluasi.jakarta: Gramedia, 2004.

Setiady, Elly. Ilmu Sosial Budaya\& Dasar, Jakarta: Kencana Prenada MediaGroup, 2007.

Sjafrizal, Perencanaan Pembangunan Daerah Dalam Era Otonomi, Jakarta:PT. Raja Gravindo Persada, 2014.

Siagian, Sondang P. Manajemen Strategik, Bumi Aksara: Jakarta, 1982.

Sunarno. Dasar-Dasar KebijakanPublik: Kajian Proses Analisis Kebijakan,Yogyakarta: UNY, 2010.

Supriady, Britakusumah Riyadi Deddy. Perencanaan Pembangunan DaerahStrategi Menggali Potensi Dalam Mewujudkan Otonomi Daerah. PT.GRAMEDIA PUSTAKA UTAMA, 2003.

Suyanto, Bagong. Metode Penelitian Sosial, Jakarta: Kencana Pranada MediaGroup, 2005.

Subarsono, AG. Analisis Kebijakan Publik: Konsep, Teori dan AplikasiYYogyakarta: Pustaka Pelajar, 2006.
Tangkilisan, Hesel, Nogi. Evaluasi Kabijakan Publik, Penjelasan, Analisis, dan Trasformasi Pemikiran.Yogyakarta: Balairung, 2003.

Terry, George.R. Prinsip-prinsip

Manajemen. Bumi Aksara: Jakarta, 2003.

Undang-undang Nomor 25 tahun 2004 tentang Sistem Perencanaan Pembangunan Nasional.

Undang-undang Nomor 32 tahun 2004 tentang Pemerintahan Daerah.

Undang-Undang Nomor 41 Tahun 2007 tentang Organisasi Perangkat Daerah.

Peraturan Pemerintah Nomor 8 tahun 2008 tentang Tahapan Tata Carapenyusunan, Pengendalian dan Evaluasi pelaksanaan RencanaPembangunan Daerah.

Winarno, Budi. Teori dan Proses

Kebijakan Publik.Yogyakarta: Penerbit MediaPressindo, 2002.

Surat Edaran Bersama (SEB) Menteri Negara Perencanaan Pembangunan

Nasional dan Menteri Dalam Negeri No.0295/M.PPN/1/2005.050/166/S]

Bahan Pelatihan : Penyusunan Rencana Pembangunan Daerah bagi Eksekutif, Legislatif dan Organisasi Masyarakat Sipil. 
http://gerryprotokol.wordpress.com/2011/ ol/05/-perencanaan-

pembangunan-daerah. (di akses pada tanggal o9 Maret 2017. 15:45 WIB)

http://wazni.staff.unri.ac.id/pemerintahan -daerah-dilihat-dari-beberapaaspek. (di akses pada tanggal 03 Maret 2017. 20:50 WIB)

http://pkmklanri.org/2013/o2/18/pengemb angan-perencanaan-dalamperumusan-kebijakan-publik. (di akses pada tanggal 10 Maret 2017. 11:55 WIB)

http://sosbud.kompasiana.com/2011/06/17 /partisipasi-masyarakat-hanyalahmimpi-373788.html. (di akses pada tanggal 20 Maret 2017. 13:45 WIB)

http://nissa260I.blogspot.com/2011/o5/pa rtisipasi-masyarakat-dalampelaksanaan.htm/(di akses pada tanggal 26 Maret 2017. 17:23 WIB)

http://myhouse.blogspot.co.id/20I2/II/tesi s-implementasi-kebijakanpemungutan.html.(di akses pada tanggal 03 Maret 2017. 14:02 WIB). 
Jurnal Ilmu Administrasi Publik 6 (1) (2018): 58-7I 